\title{
ASSESSMENT OF DURABILITY OF THE RAIL VEHICLE COMPONENTS WITH THE USE OF DEGRADATION ANALYSIS METHOD
}

\section{OCENA TRWALOŚCI PODZESPOLÓW POJAZDÓW SZYNOWYCH Z WYKORZYSTANIEM METODY PROPAGACJI ZUŻYCIA}

\author{
Stanisław Młynarski, Maciej Szkoda, Grzegorz Kaczor \\ Cracow University of Technology, Institute of Rail Vehicles
}

\begin{abstract}
An important issue during the operation of rail vehicles is the dynamics of forced loads. The identification of these workloads and the evaluation of their impact on the reliability and durability of the structure is essential for maintaining the safety of operation. For this reason, an important issue in the assessment of durability is to identify potential hazards that cause object failure. This paper presents the results of fatigue tests for the selected structure of a rail bogie. The results were then used to conduct the Degradation Analysis of the object. The purpose of this analysis was to estimate the real values of the durability and reliability indicators of the bogie frame from the point of view of the safety of its operation.
\end{abstract}

Keywords: degradation analysis, reliability assessment, railway boogie

Streszczenie: Istotnym problemem $w$ eksploatacji pojazdów szynowych jest dynamika obciażeń wymuszających. Identyfikacja tych obciażeń $i$ ocena ich wptywu na niezawodność i trwatość konstrukcji ma podstawowe znaczenie dla zachowania bezpieczeństwa użytkowania. $Z$ tego też względu ważnym zagadnieniem $w$ ocenie trwałości jest identyfikacja potencjalnych zagrożeń prowadzacych do uszkodzenia obiektów. W pracy przedstawiono wyniki badań zmęczeniowych wybranej konstrukcji wózka kolejowego, które postużyly do przeprowadzenia analizy propagacji zużcia wspomnianego obiektu. Celem tej analizy było oszacowanie rzeczywistych wartości wskaźników trwatości i niezawodności ramy wózka z punktu widzenia bezpieczeństwa jej użytkowania.

Słowa kluczowe: analiza propagacji zużycia, ocena niezawodności, wózek pojazdu szynowego 
Assessment of durability of the rail vehicle components with the use of degradation... Ocena trwalości podzespołów pojazdów szynowych z wykorzystaniem metody...

\section{ASSESSMENT OF DURABILITY OF THE RAIL VEHICLE COMPONENTS WITH THE USE OF DEGRADATION ANALYSIS METHOD}

\section{Introduction}

The introduction of a new technical object into operation requires numerous research tests which refer to the verification of a structure behaviour in the real operating conditions. This procedure is significantly important, especially for such objects as rail vehicles and their elements. This research refers primarily to the analysis of workloads resulting from the structure's operational tasks and the need for ensuring safety of vehicle operation.

The final results of the research include the determination of the indicators which characterize such properties as: non-damageability, readiness, maintenance flexibility, and safety. Each indicator is characterized by specified number measures which inform about, for instance, a vehicle capability of being suitable for running, repair time duration, or the frequency of damage occurrence.

Determining the values of these indicators should be verified on the real operational data of prototype objects or it should be confirmed by the results of laboratory tests conducted on the adequate models of an analysed object. In laboratory research, it is necessary to map real operational conditions which are important for the conducted tests. The obtained data on the operation time and damage occurrence constitutes the basis for an analysis and inference about the real durability in the determined operational conditions.

In some rail vehicle subassemblies, e.g. a bogie frame, damage can occur suddenly or can develop over time. The structure of a typical rail vehicle bogie is a spatial construction. The specified elements of this structure are joined by welding. Welds constitute a group of sensitive localizations in a bogie frame structure and they were carefully observed during strength tests.

Welds are frequently subjected to the concentration of stresses thus being potential spots of the initiation and propagation of cracks. We observe such occurrences as microcracking in the weld and the propagation of this crack to a critical size. Such occurrences have a significant meaning in maintaining safety in railway traffic.

One of the methods which may be used to evaluate the durability of a bogie frame on the basis of the results of model research is a method of wear propagation (Degradation Analysis), which was proposed in the Weibull++ program. In this paper the authors applied the results of fatigue tests and the wear propagation method to evaluate the durability of a rail vehicle bogie structure [12]. 


\section{Characteristic of the object of the analysis}

The aim of the analysis is to evaluate the durability of the frame of a four-wheel bogie of an electric train unit adjusted to the maximum speed of $160 \mathrm{~km} / \mathrm{h}$. The bogie frame was made as a spatial one-peremeter open frame. It consists of two bogie sole-bars welded into a closed box cross-section. The sole-bars were connected with each other by the pipe cross-members. The longitudinal members have socks at their ends for fitting primary suspension springs.

Pipes and brackets were mounted to the sole-bars between the cross-members and the wheel sets. The brackets were used to mount e.g. disc brake clamp mechanisms. In the lower middle part of each longitudinal member the brackets of the secondary suspension pneumatic springs were mounted. Also, the brackets of the wheel set steering system and the damping system were mounted to the frame sole-bars.

A bogie primary suspension was made in a form of four concentric sets of coil springs. These springs were mounted on the bodies of bearing blocks which also act as the equalizers of the wheel set steering system. Four pneumatic springs were used in a bogie secondary suspension: two for each of the neighbouring bodies of rail vehicle sections which are directly connected one to another above the bogie. They are additionally equipped with emergency springs which enable the continuation of running at a limited speed when the pneumatic bellows are punctured.

A bogie vibration damping system was designed in a form of hydraulic shock absorbers. In primary suspension, damping of vertical vibrations is achieved by four hydraulic shock absorbers localized in direct vicinity to the sets of coil springs. Vertical vibrations of a secondary suspension are attenuated by four dampers localized between the upper plates of pneumatic springs and the bogie frame, two dampers on each side of the bogie.

Dampening of the body transverse vibration is done by two hydraulic shock absorbers which connect the bogie frame with a link that co-operates with a king pin. Bogie swaying is prevented by four horizontal hydraulic shock absorbers which connect the bogie frame with the bodies of neighbouring sections $[1,2,4,5,6,14,18]$.

\section{The evaluation of durability and reliability of the bogie frame structure}

The durability of the structure and its selected elements was characterised by the evaluation of time required to reach the critical values of crack propagation and the identification of this event with structure damage $\left(t_{p}\right)$ and time between next damage occurrences $\left(t_{\mathrm{m}}\right)$, as well as by functional characteristics of these values. Primary reliability indexes such as a reliability function, density, and damage intensity characterize the structure properties and they are also clearly determined by inducing factors and wear processes which occur during operation $[9,21]$. 
Assessment of durability of the rail vehicle components with the use of degradation... Ocena trwatości podzespolów pojazdów szynowych z wykorzystaniem metody...

The reliability analysis of the frame subjected to dynamic loads at a test stand was carried out in order to research the influence of operational factors on the durability and reliability of the structure in working conditions.

The structure was subjected to changeable loads corresponding to the real ones, reduced to the research time. Empirical (laboratory) data collected for a prototype frame constituted the basis for the analysis.

Probabilistic models adjusted to the obtained research results and the characteristics of reliability indexes determined for them were the basis for a further analysis of the durability and reliability of the structure's elements. Verification of the model and distribution parameters was done with the use of the Maximum Likelihood (MLE) method - in the Weibull++ program.

The analysis of determined characteristics enables obtaining significant information that refers to the safety of the tested frame's operation in a determined durability time. The type of the model allows for the inference about the domination of the character of damaging factors. The reliability function presents the probability of proper operation without damage in a specified time and conditions. It also serves as a good durability comparison for the analysed objects. Damage intensity is an important reliability index. The character of this characteristic determines the risk of damage during the object's operation. The values of the function of damage intensity probability characterize the bogie frame's safe working time and determine the frame's durability $[15,16,20]$.

The characteristics of damage density are useful for ensuring safe operation and sensible control servicing. Their observation within the obtained values enables the measurement of the damage rate and allows for the inference about the time of damage accumulation and inspection planning or the introduction of changes into the object's structure. It is especially important in planning such activities that prevent serious catastrophic damage.

Inference on the basis of empirical reliability characteristics constitutes one of the fundamental elements for further research into the durability evaluation of the bogie frame in the real operational conditions. The performed stand tests yielded information about cracks and their propagation during subsequent workloads of the tested structure. The obtained data was used to calculate reliability indexes whose values are the basis for the evaluation of the durability of the bogie frame. The analysis of the characteristics provided information about the behaviour of the bogie frame structure in the real operational conditions $[7,10,17]$.

\section{Methodology and laboratory tests of the rail vehicle bogie frame}

The analysis was based on the results of fatigue tests run on the bogie frame structure. The range and the program of fatigue research of the bogie frame was prepared according to the guidelines included in the PN-EN 13749:2011 standard and the DVS 1612 directive $[3,5]$. 
The research included:

- preliminary inspection of the bogie frame,

- building tensometric installation,

- static examinations of the bogie frame,

- fatigue examinations comprising 3 stages,

- defectoscopic tests carried out with the use of a magnetic-powder method.

The parameters of the environment and the test stand: temperature $(23 \pm 5)^{\circ} \mathrm{C} ; 100 \%$ of accessible welds were tested. The tests were done in stages. The tests were conducted in ten stages of dynamic loads induced by forced cyclic vibrations on the test stand.

In compliance with the procedure, static research was performed at the beginning of a research schedule, measurements were taken after a cycle of static loads of the frame mounted on the test stand.

The remaining stages - examination was conducted on the frame placed on the test stand in compliance with PN-EN ISO 17638:2010.

The results of empirical fatigue research were processed with the use of an interval algorithm of events probability verification for the need of time estimation to the occurrence of the next damage in a form of cracking of the frame structure welds. Then, the results were expressed as the years of the vehicle's operation. This data was necessary for the determination of a probability distribution model, distribution parameters, and the reliability indicators in order to evaluate the duration of the examined frame. The analysis of the determined indicators $\lambda(t), f(t)$ and $F(t)$ provided the basis for the inference about future duration values of the examined structure of a rail vehicle bogie frame.

\section{Test stand examinations of the rail vehicle bogie frame}

The examination procedure included first of all static tests during which the frame was subjected to limit static loads. The results of these tests did not indicate the exceeding of permissible values of critical stresses and the geometric parameters of the structure. At the same time, the static tests did not show any influence of the specified loads on the frame's reliability properties and an increase in the operational risk.

The next stage of the research referred to the influence of changeable loads on the bogie frame structure durability. Results of fatigue tests were used in the reliability and duration analysis. The results were the basis for the estimation of reliability indicators and structure duration within the range of safe operation.

The aim of the conducted research was to determine the fatigue strength of the bogie frame by detecting structure damage generated during fatigue loads. The welds that connect the structure elements and the area where stresses accumulated received special attention. The measurements were taken in ten successive load cycles. 
Assessment of durability of the rail vehicle components with the use of degradation... Ocena trwatości podzespołów pojazdów szynowych z wykorzystaniem metody...

The damage to the frame structure in a form of weld cracking in the following ranges of the number of vibration cycles of the performed test were registered according to the following plan:

- stage I - up to $1 \times 10^{6}$ fatigue load cycles - after finishing stage I of loading indications in a form of cracks were detected: $\mathrm{W} 1-0.5 \mathrm{~mm}, \mathrm{~W} 2-0.6 \mathrm{~mm}$, $\mathrm{W} 3-0.2 \mathrm{~mm}$, W4 $-0.4 \mathrm{~mm}, \mathrm{~W} 5-0.2 \mathrm{~mm}$, W6 $-0.5 \mathrm{~mm}$.

- stage II - up to $2 \times 10^{6}$ fatigue load cycles - after finishing stage II in the range from $1 \times 10^{6}$ to $2 \times 10^{6}$ load cycles indications in a form of cracks were detected: $\mathrm{W} 1-0.6 \mathrm{~mm}, \mathrm{~W} 2-0.6 \mathrm{~mm}, \mathrm{~W} 3-0.5 \mathrm{~mm}, \mathrm{~W} 4-0.4 \mathrm{~mm}$, W5 $-0.2 \mathrm{~mm}$, $\mathrm{W} 6-0.7 \mathrm{~mm}$.

- stage III - up to $3 \times 10^{6}$ fatigue load cycles - after finishing stage III in the range from $2 \times 10^{6}$ to $3 \times 10^{6}$ load cycles indications in a form of cracks were detected: $\mathrm{W} 1-0.6 \mathrm{~mm}, \mathrm{~W} 2-0.6 \mathrm{~mm}, \mathrm{~W} 3-0.5 \mathrm{~mm}, \mathrm{~W} 4-0.7 \mathrm{~mm}$, $\mathrm{W} 5-0.3 \mathrm{~mm}, \mathrm{~W} 6-0.7 \mathrm{~mm}$.

- stage IV - up to $4 \times 10^{6}$ fatigue load cycles - after finishing stage IV in the range from $3 \times 10^{6}$ to $4 \times 10^{6}$ load cycles indications in a form of cracks were detected: $\mathrm{W} 1-0.8 \mathrm{~mm}, \quad \mathrm{~W} 2-0.8 \mathrm{~mm}, \quad \mathrm{~W} 3-0.6 \mathrm{~mm}, \quad \mathrm{~W} 4-0.7 \mathrm{~mm}$, $\mathrm{W} 5-0.3 \mathrm{~mm}, \mathrm{~W} 6-0.9 \mathrm{~mm}$.

- stage V - up to $5 \times 10^{6}$ fatigue load cycles - after finishing stage $\mathrm{V}$ in the range from $4 \times 10^{6}$ to $5 \times 10^{6}$ load cycles indications in a form of cracks were detected: $\mathrm{W} 1-1.0 \mathrm{~mm}, \mathrm{~W} 2-0.8 \mathrm{~mm}, \mathrm{~W} 3-0.6 \mathrm{~mm}, \mathrm{~W} 4-0.8 \mathrm{~mm}$, W5 $-0.3 \mathrm{~mm}$, W6 - $1.1 \mathrm{~mm}$.

- stage VI - up to $6 \times 10^{6}$ fatigue load cycles - after finishing stage VI in the range from $5 \times 10^{6}$ to $6 \times 10^{6}$ load cycles indications in a form of cracks were detected: $\mathrm{W} 1-1.0 \mathrm{~mm}, \quad \mathrm{~W} 2-1.2 \mathrm{~mm}, \quad \mathrm{~W} 3-0.8 \mathrm{~mm}, \quad \mathrm{~W} 4-0.8 \mathrm{~mm}$, W5 $-0.3 \mathrm{~mm}, \mathrm{~W} 6-1.3 \mathrm{~mm}$.

- stage VII - up to $7 \times 10^{6}$ fatigue load cycles - after finishing stage VII in the range from $6 \times 10^{6}$ to $7 \times 10^{6}$ load cycles indications in a form of cracks were detected: $\mathrm{W} 1-1.0 \mathrm{~mm}, \quad \mathrm{~W} 2-1.3 \mathrm{~mm}, \quad \mathrm{~W} 3-0.8 \mathrm{~mm}, \quad \mathrm{~W} 4-1.0 \mathrm{~mm}$, W5 $-0.5 \mathrm{~mm}, \mathrm{~W} 6-1.3 \mathrm{~mm}$.

- stage VIII - up to $8 \times 10^{6}$ fatigue load cycles - after finishing stage VIII in the range from $7 \times 10^{6}$ to $8 \times 10^{6}$ load cycles indications in a form of cracks were detected: $\mathrm{W} 1-1.2 \mathrm{~mm}, \mathrm{~W} 2-1.3 \mathrm{~mm}, \mathrm{~W} 3-1.2 \mathrm{~mm}, \mathrm{~W} 4-1.2 \mathrm{~mm}$, W5 $-0.6 \mathrm{~mm}, \mathrm{~W} 6-1.6 \mathrm{~mm}$.

- stage IX - up to $9 \times 10^{6}$ fatigue load cycles - after finishing stage IX in the range from $8 \times 10^{6}$ to $9 \times 10^{6}$ load cycles indications in a form of cracks were detected: $\mathrm{W} 1-1.4 \mathrm{~mm}, \mathrm{~W} 2-1.6 \mathrm{~mm}, \mathrm{~W} 3-1.3 \mathrm{~mm}, \mathrm{~W} 4-1.6 \mathrm{~mm}$, W5 - $0.9 \mathrm{~mm}, \mathrm{~W} 6-1.8 \mathrm{~mm}$.

- stage $\mathrm{X}$ - up to $10 \times 10^{6}$ fatigue load cycles - after finishing stage $\mathrm{X}$ in the range from $9 \times 10^{6}$ to $10 \times 10^{6}$ load cycles indications in a form of cracks were detected: $\mathrm{W} 1-1.8 \mathrm{~mm}, \quad \mathrm{~W} 2-1.7 \mathrm{~mm}, \mathrm{~W} 3-1.5 \mathrm{~mm}, \mathrm{~W} 4-2.0 \mathrm{~mm}$, W5 - $1.2 \mathrm{~mm}, \mathrm{~W} 6-2.2 \mathrm{~mm}$. 
The results of the conducted tests are shown in a concise form in Table 1.

Tab. 1 Data referring to the value (expressed in $\mathrm{mm}$ ) of frame structure weld cracks in the successive stages of fatigue tests

\begin{tabular}{|c|c|c|c|c|c|c|c|c|c|c|}
\hline \multirow{2}{*}{$\begin{array}{r}\text { Indication } \\
\text { number }\end{array}$} & \multicolumn{10}{|c|}{ Number of fatigue research test cycles } \\
\hline & $1 \times 10^{6}$ & $2 \times 10^{6}$ & $3 \times 10^{6}$ & $4 \times 10^{6}$ & $5 \times 10^{6}$ & $6 \times 10^{6}$ & $7 \times 10^{6}$ & $8 \times 10$ & $9 \times 10^{6}$ & $10 \times 10^{6}$ \\
\hline W1 & 0.5 & 0.6 & 0.6 & 0.8 & 1.0 & 1.0 & 1.0 & 1.2 & 1.4 & 1.8 \\
\hline $\mathrm{W} 2$ & 0.6 & 0.6 & 0.6 & 0.8 & 0.8 & 1.2 & 1.3 & 1.3 & 1.6 & 1.7 \\
\hline W3 & 0.2 & 0.5 & 0.5 & 0.6 & 0.6 & 0.8 & 0.8 & 1.2 & 1.3 & 1.5 \\
\hline W4 & 0.4 & 0.4 & 0.7 & 0.7 & 0.8 & 0.8 & 1.0 & 1.2 & 1.6 & 2.0 \\
\hline W5 & 0.2 & 0.2 & 0.3 & 0.3 & 0.3 & 0.3 & 0.5 & 0.6 & 0.9 & 1.2 \\
\hline W6 & 0.5 & 0.7 & 0.7 & 0.9 & 1.1 & 1.3 & 1.3 & 1.6 & 1.8 & 2.2 \\
\hline
\end{tabular}

The results of dynamic tests obtained for the succesive stages create a set of information about a tested structure damage. The set refers respectively to the intervals of operation time of the analysed bogie frame. The analysis of propagation of successive identified cracks characterises the process of degradation of the structure resulting from inducing factors which influence the frame structure material's fatigue. The inference that refers to the progress of the structure degradation was conducted with the use of the probabilistic models of probability distribution and with the determination of a critical value of crack propagation.

\section{Probabilistic analysis of damage and durability estimation}

The reliability analysis was conducted on the basis of the obtained research results. The results of empirical fatigue tests were processed with the use of a testing algorithm and the verification of adjusting of event probability by the method of the maximum likelihood MLE in the Weibull++ program. Probabilistic models of crack propagation observed in the successive stages of research were verified and applied. Then, the number of induction cycles was determined until the moment of reaching the boundary values of the propagation of the observed cracks.

As a result of the performed verification of probability distribution models with the use of the maximum likelihood method a two-parameter model of exponential distribution was applied as a crack propagation model for the observed degradation of the frame structure. The reliability function of the crack propagation model is given as (1) [11,13]:

$$
R(t)=e^{-\lambda(t-\gamma)}
$$

where:

$\lambda$ - parameter of damage intensity,

$\gamma$-parameter of localization. 
Assessment of durability of the rail vehicle components with the use of degradation... Ocena trwałości podzespołów pojazdów szynowych z wykorzystaniem metody...

A necessary condition for the estimation of frame durability was the determination of a crack propagation boundary value for the examined structure. For the need of conducted research a crack critical value of $3 \mathrm{~mm}$ was accepted. The value was determined in the standards for conducting fatigue tests of the elements of a rail vehicle structure. Figure 1 presents characteristics of the adjusting of exponential distribution to empirical data, respectively to each of the observed indications.

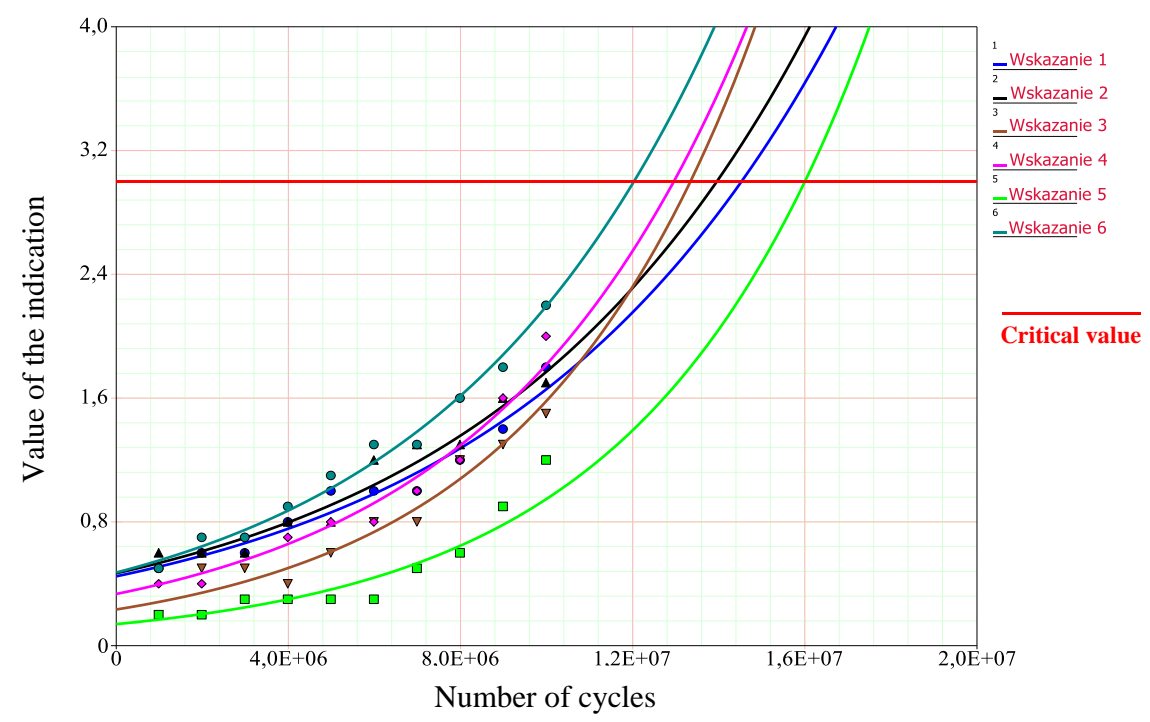

Fig. 1 Adjusting the exponential distribution to empirical data

Table 2 contains calculated parameter values of the exponential distribution for the indications observed during the tests.

Tab. 2 Estimated parameter values of the exponential distribution for the observed crack propagation

\begin{tabular}{|c|c|c|}
\hline \multirow{2}{*}{ Indication number } & \multicolumn{2}{|c|}{ Exponential distribution } \\
\cline { 2 - 3 } & $\lambda[1 /$ cycle $]$ & $\gamma$ \\
\hline W1 & $1,308767 \cdot 10^{-7}$ & 0,448002 \\
\hline W2 & $1,331323 \cdot 10^{-7}$ & 0,467977 \\
\hline W3 & $1,913162 \cdot 10^{-7}$ & 0,233602 \\
\hline W4 & $1,694182 \cdot 10^{-7}$ & 0,334047 \\
\hline W5 & $1,918339 \cdot 10^{-7}$ & 0,139281 \\
\hline W6 & $1,536321 \cdot 10^{-7}$ & 0,472587 \\
\hline
\end{tabular}


The forecast of propagation parameters for each indicated crack conducted for the horizon of the boundary cracking value leads to the determination of the load cycle number in order to reach the determined critical parameter value of the structure weld cracking.

It is illustrated in Figure 1, where the points of the crossing of propagation characteristics for particular indications with a line corresponding to the cracking critical value constitute a set of data on damage of successive welds. These values are presented in Table 2. Moreover, Table 2 contains values of time to damage in years. These values result from the number of load cycles, according to the PN-EN 13749:201 standard and the DVS 1612 directive $[3,5]$.

Tab. 3 Estimated time to weld damage

\begin{tabular}{|c|c|c|}
\hline $\begin{array}{c}\text { Indication } \\
\text { number }\end{array}$ & $\begin{array}{c}\text { Number of cycles to weld } \\
\text { damage }\end{array}$ & Time to weld damage [years] \\
\hline W1 & 14529478,91 & 44,00 \\
\hline W2 & 13955653,40 & 42,00 \\
\hline W3 & 13343092,71 & 40,00 \\
\hline W4 & 12956616,96 & 39,00 \\
\hline W5 & 16002786,04 & 48,00 \\
\hline W6 & 12029687,04 & 36,00 \\
\hline
\end{tabular}

The obtained results were further processed for the need of determining a model and the parameters of probability distribution, and then reliability indicators. They were used for the evaluation of both operation safety and operational properties of the examined frame. The analysis of the determined indicators $R(\mathrm{t}), \lambda(\mathrm{t}), f(\mathrm{t})$ and $F(\mathrm{t})$ constituted the basis for the inference about the values of durability of the tested structure of a rail vehicle bogie frame.

The adjusting of the model was done as before by applying a process of testing of compatibility with selected theoretical models (Kołmogorov-Smirnow's, Pearson's) using the maximum likelihood method for empirical data from Table 2. A logarithmic-normal distribution was chosen for further analysis on the basis of the obtained results. The parameters of distribution adjusting were calculated. The function of probability density of this distribution is presented as a relation (2) $[8,11,13,22]$ :

$$
f\left(t^{\prime}\right)=\frac{1}{\sigma^{\prime} \sqrt{2 \pi}} e^{-\frac{1}{2}\left(\frac{t^{\prime}-\mu^{\prime}}{\sigma^{\prime}}\right)^{2}}
$$

where:

$\mathrm{t}^{\prime}=\ln (\mathrm{t}) \cdot \mathrm{t}=$ values of the random variable

$\mu$ ' - shape parameter

$\sigma^{\prime}$ - scale parameter 
Assessment of durability of the rail vehicle components with the use of degradation... Ocena trwałości podzespołów pojazdów szynowych z wykorzystaniem metody...

Determined values of the logarithmic-normal distribution parameters are as follows: $\mu^{\prime}=16,436312, \quad \sigma^{\prime}=0,09857$

Figure 2 shows respectively: the characteristic of the reliability function and the characteristic of the distribution function of a logarithmic-normal distribution for the estimated values of time to damage of a rail vehicle bogie frame.
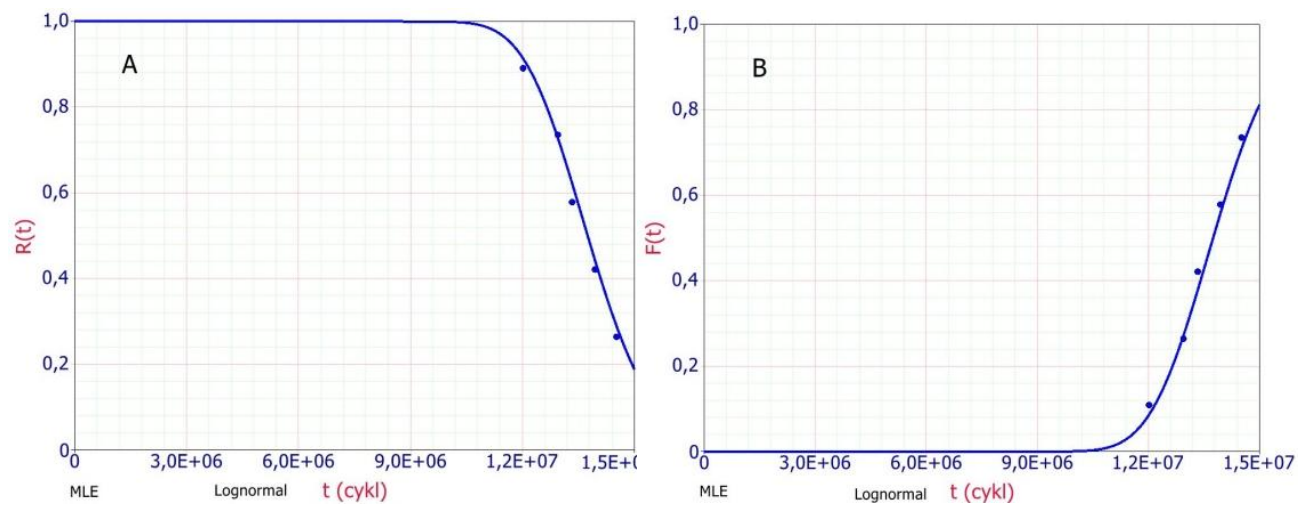

Fig. 2 Characteristic of the reliability function $R(t)$ : A, the distribution function $F(t)$, $B$ presented within the range of an expected horizon of the durability range $1,5 \cdot 10^{7}$ of induction cycles in bogie frame operation.

Damage intensity is an important reliability index for the evaluation of bogie frame durability in order to maintain operation safety. The value of this index expresses the risk of damage and stimulates the level of maintaining safety in the operation of a rail vehicle.

Figure 3 refers to the intensity function and the density of damage probability in a logarithmic-normal distribution for the value of time to the structure damage.
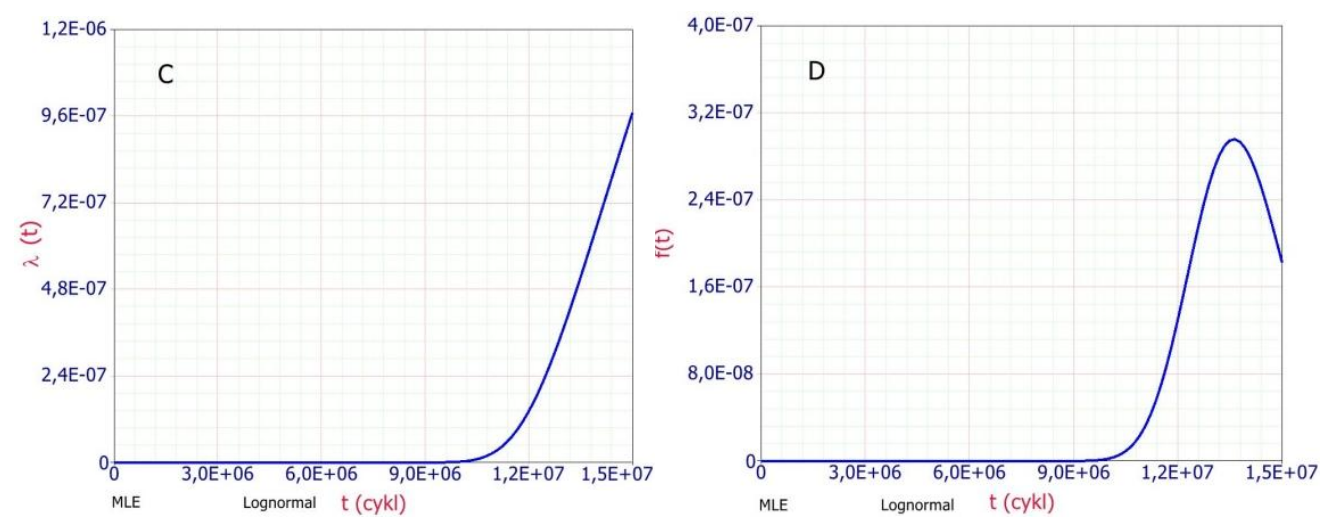

Fig. 3 Characteristic of the damage intensity function $\lambda(t)$ : $C$, damage density $f(t)$, $D$ presented within the range of an expected horizon of the durability range to $1,5 \cdot 10^{7}$ of induction cycles in bogie frame operation. 
Determining the boundary values of the index $\lambda(t)$ is a condition for defining a boundary value of the durability of a bogie frame structure. Forecasting on the basis of research results enables the estimation of the maximum values of damage intensity $\lambda(\mathrm{t})$ and damage density $f(t)$. These values determine both the risk of frame damage and the maintaining of operation safety in an analysed horizon of the operation time $\mathrm{T}$.

Durability expressed as a number of load cycles was calculated on the basis of the observation of chosen characteristics and the determination of their boundary values.

The durability of the examined bogie frame structure as an expected ability time $E T$ in the applied logarithmic-normal distribution was evaluated on the basis of the relation (3) [11].

$$
E T=\int_{0}^{\infty} t^{\prime} \cdot f\left(t^{\prime}\right) d t=\frac{t^{\prime}}{\sigma^{\prime} \sqrt{2 \pi}} e^{-\frac{1}{2}\left(\frac{t^{\prime}-\mu^{\prime}}{\sigma^{\prime}}\right)^{2}}
$$

After distribution: $\mu^{\prime}=16,436312, \sigma^{\prime}=0,09857 \quad \mathrm{ET}=1,38 \cdot 10^{7}$ cycles

Durability calculated in this way equals $1,38 \cdot 10^{7}$ induction cycles. It is the time of 41 years of bogie frame operation in the real operation conditions reduced to the sum of loads.

The verification of the obtained result was achieved through the evaluation of the values of the determined reliability indicators for the calculated structure durability. The chosen indicators calculated for $\mathrm{t}=1,38 \cdot 10^{7}$ load cycles take the following values:

$$
\begin{aligned}
& \mathrm{R}\left(\mathrm{t}=1,38 \cdot 10^{7}\right)=0,484354 \\
& \mathrm{f}\left(\mathrm{t}=1,38 \cdot 10^{7}\right)=2,9500 \cdot 10^{-7} \\
& \lambda\left(\mathrm{t}=1,38 \cdot 10^{7}\right)=6,050448 \cdot 10^{-7} / \mathrm{cykl}=2,3294228 \cdot 10^{-5} / \mathrm{h}
\end{aligned}
$$

The application of the structure of a rail vehicle bogie frame to the evaluation of durability and reliability can have applied reliability standards expressed as classes of object reliability classified on the basis of the level of damage intensity.

Class $\mathrm{T}$ is adequate for the frame structure, its tasks and operation conditions. Class $\mathrm{T}$ refers to important objects for which the reliability value is required and the boundary level of damage intensity equals

$$
\lambda(\mathrm{t})_{\text {boundary }}=5 \cdot 10^{-4} / \mathrm{h}>\lambda\left(\mathrm{t}=1,38 \cdot 10^{7}\right)=2,3294228 \cdot 10^{-5} / \mathrm{h} \mathrm{[19]} .
$$

The results of the verification of the damage intensity boundary value fulfil the operation safety criterion for the durability horizon (estimated on the basis of the conducted calculations) equal to $1,38 \cdot 10^{7}$ induction cycles. 
Assessment of durability of the rail vehicle components with the use of degradation... Ocena trwałości podzespołów pojazdów szynowych z wykorzystaniem metody...

\section{Conclusions}

This paper presents the results of fatigue examinations which refer to a bogie frame. The results were used to evaluate chosen reliability and structure durability indicators. The probabilistic analysis of damage data yielded information used for inferencing about the character of factors leading to the structure damage.

Inferencing about the effects of fatigue loads in the elements of the bogie frame structure and their influence on operation durability is an important area of the analysis.

In the statistical analysis a method of Degradation Analysis available in the Reliasoft software package was applied. This tool may also be used in other engineering tasks which require processing probabilistic data in order to evaluate the values of selected measurements that characterize the durability and reliability of technical objects.

This method may be used for the evaluation of reliability indicators of prototype structures which lack operational data. The durability estimation calculated on the basis of a probabilistic prognosis of structure degradation progress which equalled 41 years of regular operation may constitute only preliminary information about the real structure durability.

Further research in real operation conditions and control of reliability indicators values in successive stages of operation for ensuring the time horizon of safe operation of a rail vehicle bogie frame are necessary.

\section{Literature}

[1] Baur K. G.: Drehgestelle - Bogies. EK-Verlag. Freiburg, 2006.

[2] DIN 27201. Zustand der Eisenbahnfahrzeuge - Grundlagen und Fertigungstechnologien - Teil 6: Schweißen.

[3] DVS1612:2009-08 Technische Regel. Gestaltung und Dauerfestigkeitsbewertung von Schweißverbindungen an Stählen im Schienenfahrzeugbau.

[4] EN 12663:2010. Railway applications. Structural requirements of railway vehicle bodies. Part 1 and 2 .

[5] EN 13749:2011. Railway applications. Wheelsets and bogies. Methods of specifying structural requirements of bogie frames.

[6] EN 15827:2011. Kolejnictwo -- Wymagania dla wózków i układów biegowych.

[7] Kadziński A.: Studium wybranych aspektów niezawodności systemów oraz obiektów pojazdów szynowych. Monografia naukowa. Wydawnictwo Politechniki Poznańskiej. Poznań, 2013.

[8] Lehmann E. L. Testowanie hipotez statystycznych. PWN. Warszawa, 1968. 
[9] Młynarski S., Pilch R., Smolnik M., Kaczor G., Szkoda M., Szybka J.: Effect of Selected Factors on The Safety Integrity Level (SIL). Journal of KONBiN 3(35) 2015, s. 85-98.

[10] Nash F.R.: Reliability assessments: concepts, models, and case studies. CRC Pres Taylor \& Francis Group, 2016.

[11] ReliaSoft Corporation: System Analysis Reference: Reliability, Availability \& Optimization. ReliaSoft Publishing. Tucson, AZ, 2009.

[12] Stapelberg R., F. Handbook of Reliability, Maintainability and Safety in Engineering Design. Springer-Verlag London Limited. Queensland, 2009.

[13] O'Connor P. Practical Reliability Engineering, 4th Edition". John Wiley \& Sons Ltd., 2010.

[14] Romaniszyn Z.: Podwozia wózkowe pojazdów szynowych. Wydawnictwo Politechniki Krakowskiej. Kraków, 2005.

[15] Pilch R.: Reliability evaluation of networks with imperfect and repairable links and nodes. Eksploatacja i Niezawodnosc - Maintenance and Reliability 2017; 19 (1): 19-25.

[16] Pilch R., Smolnik M., Szybka J., Wiązania G.: Koncepcja strategii odnów profilaktycznych na przykładzie pojazdów szynowych komunikacji miejskiej [w] Siergiejczyk M. [red.]: Problemy utrzymania systemów technicznych. Oficyna Wydawnicza Politechniki Warszawskiej, Warszawa 2014.

[17] Ramirez-Marquez J., E., Rocco C., M.: All-terminal network reliability optimization via probabilistic solution discovery. Reliability Engineering and System Safety 2008; 93: 1689-1697.

[18] Scharman D., Hiller M., Bardini R.: Vehicle dynamics, modeling and simulation, Springer - Verlag Berlin Heidelberg, 2014.

[19] Smalko Z.: Podstawy projektowania niezawodnych maszyn i urządzeń mechanicznych. PWN. Warszawa, 1972.

[20] Sowa A.: Ocena stanu technicznego pojazdów szynowych na podstawie cech zdeterminowanych. Politechnika Krakowska im. Tadeusza Kościuszki. Kraków, 2013

[21] Szkoda M., Kaczor G.: RAMS analysis of railway vehicles' lifecycle. Journal of KONBiN nr 41/2017, s. 83-106.

[22] Szkoda M., Kaczor G.: "Reliability and availability assessment of diesel locomotive using Fault Tree Analysis". Archives of Transport, 2016, Vol. 40, Issue 4, s. 79-89. 
Assessment of durability of the rail vehicle components with the use of degradation... Ocena trwalości podzespołów pojazdów szynowych z wykorzystaniem metody...

\section{OCENA TRWALOŚCI PODZESPOLÓW POJAZDÓW SZYNOWYCH Z WYKORZYSTANIEM METODY PROPAGACJI ZUŻYCIA}

\section{Wstęp}

Wprowadzenie nowego obiektu technicznego do eksploatacji wymaga przeprowadzenia licznych badań związanych $\mathrm{z}$ weryfikacją zachowania się konstrukcji w rzeczywistych warunkach użytkowania. Postępowanie to ma duże znaczenie szczególnie w przypadku takich obiektów jak pojazdy szynowe i ich elementy. Badania te dotyczą przede wszystkim analizy obciążeń wynikających z zadań roboczych konstrukcji i zapewnienia bezpieczeństwa pracy pojazdu. Wyniki badań w ostatecznej formie sprowadzają się do wyznaczenia wskaźników charakteryzujących takie właściwości jak: nieuszkadzalność, gotowość, podatność na utrzymanie oraz bezpieczeństwo. Każdy ze wskaźników charakteryzuje się określonymi miarami liczbowymi, które informują np. o zdolności pojazdu do przebywania $\mathrm{w}$ stanie zdatności, czasie trwania naprawy czy częstości występowania uszkodzeń. Wyznaczenie wartości tych wskaźników powinno zostać zweryfikowane na rzeczywistych danych eksploatacyjnych obiektów prototypowych lub potwierdzone wynikami stanowiskowych badań laboratoryjnych, prowadzonych na odpowiednich modelach analizowanego obiektu. W przypadku badań laboratoryjnych konieczne jest odwzorowanie istotnych dla prowadzonych badań warunków rzeczywistej eksploatacji. Zgromadzone dane dotyczące czasu eksploatacji i występowania uszkodzeń stanowią podstawę do analizy i wnioskowania o rzeczywistej trwałości w zadanych warunkach eksploatacji. W przypadku niektórych podzespołów pojazdów szynowych, takich jak np. rama wózka kolejowego, pojawienie się uszkodzenia może występować w sposób nagły lub może stopniowo rozwijać się w czasie. Budowa typowego wózka pojazdu szynowego stanowi konstrukcję przestrzenną, w której określone elementy łączy się w procesie spawania. Połączenia te w postaci spoin stanowią grupę wrażliwych lokalizacji w konstrukcji ramy wózka, które w trakcie prowadzenia badań wytrzymałościowych podlegały wnikliwej obserwacji. Miejsca te są często narażone na koncentrację naprężeń i w związku z tym stanowią one potencjalne miejsca inicjacji i propagacji pęknięć. Mamy $\mathrm{w}$ tym przypadku do czynienia $\mathrm{z}$ takimi zdarzeniami jak pojawienie się mikropęknięcia $w$ spoinie oraz propagacja tego pęknięcia do krytycznych rozmiarów. Zdarzenia takie mają zasadnicze znaczenie dla zachowania bezpieczeństwa $\mathrm{w}$ ruchu kolejowym. Jedną $\mathrm{z}$ metod, która może być wykorzystana do oszacowania trwałości ramy wózka kolejowego na podstawie wyników badań modelowych jest metoda propagacji zużycia (Degradation Analysis), którą zaproponowano $\mathrm{w}$ programie Weibull++. $\mathrm{W}$ przedstawionej pracy wykorzystano wyniki badań zmęczeniowych oraz metodę propagacji zużycia do szacowania trwałości konstrukcji wózka pojazdu szynowego [12]. 


\section{Charakterystyka obiektu analizy}

Celem analizy jest ocena trwałości ramy dwuosiowego wózka tocznego elektrycznego zespołu trakcyjnego dostosowanego do prędkości maksymalnej $160 \mathrm{~km} / \mathrm{h}$. Ramę wózka wykonano w oparciu o przestrzenną, jednoobwodową ramę otwartą. Składa się ona $\mathrm{z}$ dwóch ostojnic spawanych w zamknięty przekrój skrzynkowy, które połączono ze sobą rurowymi poprzecznicami. Podłużnice na swoich końcach mają wykonane gniazda do osadzenia sprężyn I stopnia usprężynowania. Do ostojnic - pomiędzy poprzecznicami i zestawami kołowymi wspawano rury wraz ze wspornikami do mocowania m.in. mechanizmów zaciskowych hamulca tarczowego. W obniżonej, środkowej części każdej z podłużnic, osadzono wsporniki sprężyn pneumatycznych II stopnia usprężynowania. Do ostoi przymocowano ponadto m.in. wsporniki układu prowadzenia zestawów kołowych oraz układu tłumienia.

Usprężynowanie I stopnia wózka wykonano w postaci czterech współśrodkowych kompletów sprężyn śrubowych. Sprężyny te osadzono na korpusach bloków łożyskowych stanowiących równocześnie wahacze układu prowadzenia zestawów kołowych. W układzie usprężynowania II stopnia wózka zastosowano 4 sprężyny pneumatyczne - po dwie dla każdego z sąsiednich nadwozi członów pojazdów łączonych bezpośrednio ze sobą nad wózkiem. Są one dodatkowo wyposażone w sprężyny awaryjne, które $\mathrm{w}$ sytuacji przebicia miecha pneumatycznego umożliwiają kontynuowanie jazdy $\mathrm{z}$ ograniczoną prędkością. Układ tłumienia drgań w wózku wykonano w postaci amortyzatorów hydraulicznych. W I stopniu usprężynowania tłumienie drgań pionowych realizowane jest za pomocą czterech amortyzatorów hydraulicznych zlokalizowanych w bezpośrednim sąsiedztwie kompletów sprężyn śrubowych. Drgania pionowe II stopnia usprężynowania tłumione są $\mathrm{z}$ wykorzystaniem czterech tłumików umieszczonych pomiędzy górnymi płytami sprężyn pneumatycznych a ramą wózka, po dwa amortyzatory na stronę wózka. Tłumienie drgań poprzecznych nadwozia odbywa się za pomocą dwóch amortyzatorów hydraulicznych łączących ramę wózka $\mathrm{z}$ jarzmem współpracującym $\mathrm{z}$ czopem skrętu. Przeciwdziałanie wężykowaniu wózka realizowane jest za pomocą czterech poziomych amortyzatorów hydraulicznych, łączących ramę wózka z nadwoziami sąsiednich członów $[1,2,4,5,6,14,18]$.

\section{Badania trwałości i niezawodności konstrukcji ramy wózka kolejowego}

Trwałość konstrukcji i wybranych jej elementów scharakteryzowano przez ocenę czasu do osiągnięcia krytycznych wartości propagacji pęknięcia i utożsamianie tego zdarzenia $\mathrm{z}$ uszkodzeniem konstrukcji $\left(\mathrm{t}_{\mathrm{p}}\right)$ oraz czasu między kolejnymi uszkodzeniami $\left(\mathrm{t}_{\mathrm{m}}\right)$ a także poprzez charakterystyki funkcyjne tych wielkości.

Podstawowe wskaźniki niezawodności takie jak funkcja niezawodności, gęstość oraz intensywność uszkodzeń charakteryzują właściwości konstrukcji i są również wyraźnie zdeterminowane czynnikami wymuszającymi oraz zachodzącymi w trakcie eksploatacji procesami zużycia [9,21]. 
Assessment of durability of the rail vehicle components with the use of degradation... Ocena trwałości podzespołów pojazdów szynowych z wykorzystaniem metody...

W celu zbadania wpływu czynników eksploatacji na trwałość i niezawodność konstrukcji $\mathrm{w}$ warunkach pracy przeprowadzono analizę niezawodności ramy poddanej dynamicznym obciążeniom na stanowisku badawczym. Konstrukcja poddana została zmiennym obciążeniom adekwatnym do rzeczywistych, zredukowanych do czasu badania. Podstawą analizy były zgromadzone dane empiryczne (laboratoryjne) dla prototypowej ramy. Dopasowane dla uzyskanych wyników badań modele probabilistyczne oraz wyznaczone dla nich charakterystyki wskaźników niezawodności stanowiły podstawę do dalszej analizy trwałości i niezawodności elementów konstrukcji. Weryfikacji modelu oraz parametrów rozkładu dokonano $\mathrm{z}$ wykorzystaniem metody największej wiarygodności „Maximum Likelihood (MLE)” - w programie Weibull++.

Analiza wyznaczonych charakterystyk umożliwia otrzymanie istotnych informacji dotyczących bezpieczeństwa eksploatacji badanej ramy w przyjętym czasie trwałości. Rodzaj modelu daje podstawy do wnioskowania o dominacji charakteru czynników uszkadzających.

Funkcja niezawodności prezentuje prawdopodobieństwo poprawnej pracy bez uszkodzeń w określonym czasie i warunkach, stanowiąc jednocześnie dobre porównanie trwałości dla analizowanych obiektów. Ważnym wskaźnikiem niezawodności jest intensywność uszkodzeń. Charakter przebiegu tej krzywej określa ryzyko uszkodzenia w trakcie eksploatacji obiektu. Wartości przyjmowane przez funkcję prawdopodobieństwa intensywności uszkodzeń charakteryzują bezpieczny czas pracy ramy wózka i determinują jej trwałość $[15,16,20]$.

Przydatne dla zapewnienia bezpiecznej eksploatacji oraz racjonalnej obsługi kontrolnej są charakterystyki gęstości uszkodzeń. Obserwacja ich przebiegu w zakresie otrzymanych wartości umożliwia pomiar skali problemu uszkodzeń oraz pozwala na wnioskowanie o czasie kumulacji uszkodzeń i planowaniu przeglądów lub wprowadzeniu zmian w konstrukcji obiektu. Wskaźnik ten nabiera szczególnie istotnego znaczenia w planowaniu zabiegów profilaktycznych, zapobiegjących występowaniu uszkodzeń katastrofalnych. Wnioskowanie na podstawie empirycznych charakterystyk niezawodnościowych stanowi jeden z podstawowych elementów dla dalszych prac nad oszacowaniem trwałości w rzeczywistych warunkach eksploatacji ramy wózka. Przeprowadzone badania stanowiskowe dostarczyły informacji dotyczących pęknięć i ich propagacji w trakcie kolejnych obciążeń badanej konstrukcji. Uzyskane dane posłużyły do wyliczenia wskaźników niezawodności, których wartości stanowią podstawę do oszacowania trwałości przedmiotowej ramy wózka. Analiza charakterystyk dostarczyła informacji o zachowaniu się konstrukcji ramy wózka w warunkach rzeczywistej eksploatacji $[7,10,17]$. 


\section{Metodologia i badania laboratoryjne ramy wózka pojazdu szynowego}

Analizę wykonano na podstawie wyników badań zmęczeniowych konstrukcji ramy wózka kolejowego. Zakres i program badań zmęczeniowych ramy wózka został przygotowany na podstawie wytycznych zawartych w normie PN-EN 13749:2011 i dyrektywę DVS 1612 [3,5].

Badania obejmowały:

- oględziny wstępne ramy wózka,

- wykonanie instalacji tensometrycznej,

- badania statyczne ramy wózka,

- badania zmęczeniowe składające się z 3 etapów,

- badania defektoskopowe wykonane metodą magnetyczno-proszkową.

Parametry otoczenia i stanowisko badawcze: temperatura $(23 \pm 5)^{\circ} \mathrm{C}$; badaniu poddano $100 \%$ dostępnych spoin. Badania wykonane były etapami. Badania wykonane były $\mathrm{w}$ dziesięciu etapach dynamicznych obciążeń wywołanych wymuszonymi drganiami cyklicznymi na stanowisku badawczym. Zgodnie $\mathrm{z}$ procedurą badania statyczne przeprowadzono na początku harmonogramu badawczego, pomiarów dokonano po cyklu obciążeń statycznych ramy, zamontowanej na stanowisku badawczym.

Pozostałe etapy - badanie wykonano na ramie ustawionej na stanowisku badawczym, obszar badania - lico spoiny + SWC, technika magnesowania - jarzmo $\mathrm{AC}$, natężenie pola stycznego $\left(3^{6}\right) \mathrm{kA} / \mathrm{m}$, kierunki magnesowania zgodnie z PN-EN ISO 17638:2010.

Wyniki empirycznych badań zmęczeniowych zostały przetworzone z użyciem przedziałowego algorytmu weryfikacji prawdopodobieństwa zdarzeń dla potrzeb oszacowania czasu do powstania kolejnych uszkodzeń w postaci pęknięć spoin konstrukcji ramy i następnie zredukowane do czasu wyrażonego w latach eksploatacji pojazdu. Dane te były niezbędne do wyznaczenia modelu rozkładu prawdopodobieństwa, parametrów rozkładu i następnie wskaźników niezawodności dla potrzeb oszacowania trwałości badanej ramy. Analiza wyznaczonych wskaźników $\lambda(\mathrm{t}), \mathrm{f}(\mathrm{t})$ i $\mathrm{F}(\mathrm{t})$ dała podstawy do wnioskowania o przyszłych wartościach trwałości badanej konstrukcji ramy wózka tocznego pojazdu szynowego.

\section{Badania stanowiskowe ramy wózka pojazdu szynowego}

Procedura badań w pierwszej kolejności objęła badania statyczne w trakcie których konstrukcję ramy poddano granicznym obciążeniom statycznym. Wyniki z tych badań nie wykazały przekroczenia dopuszczalnych wartości naprężeń krytycznych oraz parametrów geometrycznych konstrukcji. Jednocześnie badania statyczne nie wykazały wpływu zadanych obciążeń na zmianę właściwości niezawodnościowych ramy i zwiększenie ryzyka eksploatacji.

Kolejny etap prowadzonych badań dotyczył wpływu zmiennych obciążeń na trwałość konstrukcji ramy wózka. 
Assessment of durability of the rail vehicle components with the use of degradation... Ocena trwalości podzespołów pojazdów szynowych z wykorzystaniem metody...

Do analizy niezawodności i trwałości wykorzystano wyniki badań zmęczeniowych na podstawie, których oszacowano wskaźniki niezawodności oraz trwałość konstrukcji w zakresie bezpiecznej eksploatacji.

Celem prowadzonych badań było określenie wytrzymałości zmęczeniowej ramy wózka przez wykrycie uszkodzeń konstrukcji powstałych podczas obciążeń zmęczeniowych. Szczególną uwagę skupiono w obszarze spoin łączących elementy konstrukcji oraz w miejsc występowania kumulacji naprężeń. Pomiarów dokonano w dziesięciu kolejnych cyklach obciążeń.

Uszkodzenia konstrukcji ramy w postaci pęknięć spoin w kolejnych zakresach liczby cykli drgań prowadzonego badania zostały zarejestrowane wg następującego planu:

- I etap - do $1 \times 10^{6}$ cykli obciążeń zmęczeniowych - po zakończeni I etapu obciążeń wykryto wskazania $\mathrm{w}$ postaci pęknięć: $\mathrm{W} 1-0,5 \mathrm{~mm}, \mathrm{~W} 2-0,6 \mathrm{~mm}$, $\mathrm{W} 3-0,2 \mathrm{~mm}, \mathrm{~W} 4-0,4 \mathrm{~mm}, \mathrm{~W} 5-0,2 \mathrm{~mm}$, W6 -0,5 mm.

- II etap - do $2 \times 10^{6}$ cykli obciążeń zmęczeniowych - po zakończeniu II etapu w zakresie od $1 \times 10^{6}$ do $2 \times 10^{6}$ cykli obciążeń wykryto wskazania w postaci pęknięć: $\mathrm{W} 1-0,6 \mathrm{~mm}, \quad \mathrm{~W} 2-0,6 \mathrm{~mm}, \mathrm{~W} 3-0,5 \mathrm{~mm}, \mathrm{~W} 4-0,4 \mathrm{~mm}$, $\mathrm{W} 5-0,2 \mathrm{~mm}, \mathrm{~W} 6-0,7 \mathrm{~mm}$.

- III etap - do $3 \times 10^{6}$ cykli obciążeń zmęczeniowych - po zakończeniu III etapu w zakresie od $2 \times 10^{6}$ do $3 \times 10^{6}$ cykli obciążeń wykryto wskazania w postaci pęknięć: $\mathrm{W} 1-0,6 \mathrm{~mm}, \mathrm{~W} 2-0,6 \mathrm{~mm}, \mathrm{~W} 3-0,5 \mathrm{~mm}, \mathrm{~W} 4-0,7 \mathrm{~mm}$, $\mathrm{W} 5-0,3 \mathrm{~mm}, \mathrm{~W} 6-0,7 \mathrm{~mm}$.

- IV etap - do $4 \times 10^{6}$ cykli obciążeń zmęczeniowych - po zakończeniu IV etapu w zakresie od $3 \times 10^{6}$ do $4 \times 10^{6}$ cykli obciążeń wykryto wskazania w postaci pęknięć: $\mathrm{W} 1-0,8 \mathrm{~mm}, \mathrm{~W} 2-0,8 \mathrm{~mm}, \mathrm{~W} 3-0,6 \mathrm{~mm}, \mathrm{~W} 4-0,7 \mathrm{~mm}$, W5 - 0,3 mm, W6-0,9 mm.

- V etap - do $5 \times 10^{6}$ cykli obciążeń zmęczeniowych - po zakończeniu V etapu w zakresie od $4 \times 10^{6}$ do $5 \times 10^{6}$ cykli obciążeń wykryto wskazania w postaci pęknięć: $\mathrm{W} 1-1,0 \mathrm{~mm}, \quad \mathrm{~W} 2-0,8 \mathrm{~mm}, \mathrm{~W} 3-0,6 \mathrm{~mm}, \mathrm{~W} 4-0,8 \mathrm{~mm}$, W5 - 0,3 mm, W6-1,1 mm.

- VI etap - do $6 \times 10^{6}$ cykli obciążeń zmęczeniowych - po zakończeniu VI etapu w zakresie od $5 \times 10^{6}$ do $6 \times 10^{6}$ cykli obciążeń wykryto wskazania w postaci pęknięć: W1 $-1,0 \mathrm{~mm}, \mathrm{~W} 2-1,2 \mathrm{~mm}, \mathrm{~W} 3-0,8 \mathrm{~mm}, \mathrm{~W} 4-0,8 \mathrm{~mm}$, W5 - 0,3 mm, W6 - 1,3 mm.

- VII etap - do 7 x $10^{6}$ cykli obciążeń zmęczeniowych - po zakończeniu VII etapu w zakresie od $6 \times 10^{6}$ do $7 \times 10^{6}$ cykli obciążeń wykryto wskazania w postaci pęknięć: W1-1,0 mm, W2-1,3 mm, W3-0,8 mm, W4-1,0 mm, W5 - 0,5 mm, W6 - 1,3 mm.

- VIII etap - do $8 \times 10^{6}$ cykli obciążeń zmęczeniowych - po zakończeniu VIII etap w zakresie od $7 \times 10^{6}$ do $8 \times 10^{6}$ cykli obciążeń wykryto wskazania w postaci pęknięć: $\mathrm{W} 1-1,2 \mathrm{~mm}, \mathrm{~W} 2-1,3 \mathrm{~mm}, \mathrm{~W} 3-1,2 \mathrm{~mm}, \mathrm{~W} 4-1,2 \mathrm{~mm}$, W5 - 0,6 mm, W6-1,6 mm. 
- IX etap - do 9 × $10^{6}$ cykli obciążeń zmęczeniowych - po zakończeniu IX etapu w zakresie od $8 \times 10^{6}$ do 9x $10^{6}$ cykli obciążeń wykryto wskazania w postaci pęknięć: $\mathrm{W} 1-1,4 \mathrm{~mm}, \mathrm{~W} 2-1,6 \mathrm{~mm}, \mathrm{~W} 3-1,3 \mathrm{~mm}, \mathrm{~W} 4-1,6 \mathrm{~mm}$, W5 - 0,9 mm, W6 - 1,8 mm.

- X etap - do 10 x $10^{6}$ cykli obciążeń zmęczeniowych - po zakończeniu X etapu w zakresie od $9 \times 10^{6}$ do $10 \times 10^{6}$ cykli obciążeń wykryto wskazania w postaci pęknięć: $\mathrm{W} 1-1,8 \mathrm{~mm}, \mathrm{~W} 2-1,7 \mathrm{~mm}, \mathrm{~W} 3-1,5 \mathrm{~mm}, \mathrm{~W} 4-2,0 \mathrm{~mm}$, W5 - 1,2 mm, W6-2,2 mm.

Wyniki prowadzonych pomiarów w postaci syntetycznej przedstawiono w tabeli $\mathrm{nr} 1$.

Tab. 1 Dane dotyczace wielkości wyrażonej w mm pęknięć spoin konstrukcji ramy w kolejnych etapach badań zmęczeniowych

\begin{tabular}{|c|c|c|c|c|c|c|c|c|c|c|}
\hline \multirow{2}{*}{$\begin{array}{c}\text { Nr } \\
\text { wskazania }\end{array}$} & \multicolumn{10}{|c|}{ Liczba cykli badań zmęczeniowych } \\
\cline { 2 - 13 } & $1 \times 10^{6}$ & $2 \times 10^{6}$ & $3 \times 10^{6}$ & $4 \times 10^{6}$ & $5 \times 10^{6}$ & $6 \times 10^{6}$ & $7 \times 10^{6}$ & $8 \times 10^{6}$ & $9 \times 10^{6}$ & $10 \times 10^{6}$ \\
\hline W1 & 0,5 & 0,6 & 0,6 & 0,8 & 1,0 & 1,0 & 1,0 & 1,2 & 1,4 & 1,8 \\
\hline W2 & 0,6 & 0,6 & 0,6 & 0,8 & 0,8 & 1,2 & 1,3 & 1,3 & 1,6 & 1,7 \\
\hline W3 & 0,2 & 0,5 & 0,5 & 0,6 & 0,6 & 0,8 & 0,8 & 1,2 & 1,3 & 1,5 \\
\hline W4 & 0,4 & 0,4 & 0,7 & 0,7 & 0,8 & 0,8 & 1,0 & 1,2 & 1,6 & 2,0 \\
\hline W5 & 0,2 & 0,2 & 0,3 & 0,3 & 0,3 & 0,3 & 0,5 & 0,6 & 0,9 & 1,2 \\
\hline W6 & 0,5 & 0,7 & 0,7 & 0,9 & 1,1 & 1,3 & 1,3 & 1,6 & 1,8 & 2,2 \\
\hline
\end{tabular}

Uzyskane dla kolejnych etapów wyniki badań dynamicznych stanowią zbiór informacji o uszkodzeniach badanej konstrukcji, odnoszący się odpowiednio do określonych przedziałów czasu eksploatacji analizowanej ramy wózka. Analiza propagacji kolejnych zidentyfikowanych pęknięć charakteryzuje proces degradacji konstrukcji w wyniku czynników wymuszających, oddziałujących na zmęczenie materiału elementów konstrukcji ramy. Wnioskowanie dotyczące postępu degradacji konstrukcji przeprowadzono $\mathrm{z}$ wykorzystaniem probabilistycznych modeli rozkładu prawdopodobieństwa i wyznaczeniu krytycznej wartości propagacji pęknięcia.

\section{Analiza probabilistyczna uszkodzeń i szacowanie trwałości}

Analizę niezawodności przeprowadzono na podstawie uzyskanych wyników badań. Wyniki empirycznych badań zmęczeniowych zostały przetworzone $\mathrm{z}$ użyciem algorytmu testowania i weryfikacji dopasowania prawdopodobieństwa zdarzeń metodą największej wiarygodności MLE w programie Weibull++. Zweryfikowano i zastosowano probabilistyczne modele propagacji pęknięć zaobserwowanych $\mathrm{w}$ trakcie kolejnych etapów badania. W dalszej kolejności wyznaczona została liczby cykli wymuszeń do momentu osiągnięcia granicznych wartości propagacji obserwowanych pęknięć. 
Assessment of durability of the rail vehicle components with the use of degradation... Ocena trwałości podzespołów pojazdów szynowych z wykorzystaniem metody...

W wyniku przeprowadzonej weryfikacji modeli rozkładu prawdopodobieństwa metodą największej wiarygodności dopasowania przyjęto dwuparametryczny model rozkładu wykładniczego jako model propagacji pęknięcia dla zaobserwowanej degradacji konstrukcji ramy, którego funkcja niezawodności dana jest zależnością (1) [11,13]:

$$
R(t)=e^{-\lambda(t-\gamma)}
$$

gdzie:

$\lambda$ - parametr intensywności uszkodzeń, $\gamma$-parametr położenia.

Warunkiem koniecznym dla oszacowania trwałości ramy było określenie granicznej wartości propagacji pęknięcia dla badanej konstrukcji. Dla potrzeb prowadzonego badania przyjęto wartość krytyczną pęknięcia, wynoszącą $3 \mathrm{~mm}$ określona w normie dla prowadzenia badań zmęczeniowych konstrukcji elementów pojazdów szynowych. Na rys. 1 przedstawiono wykres charakterystyk dopasowania rozkładu wykładniczego do danych empirycznych, odpowiednio na każdego z zaobserwowanych wskazań.

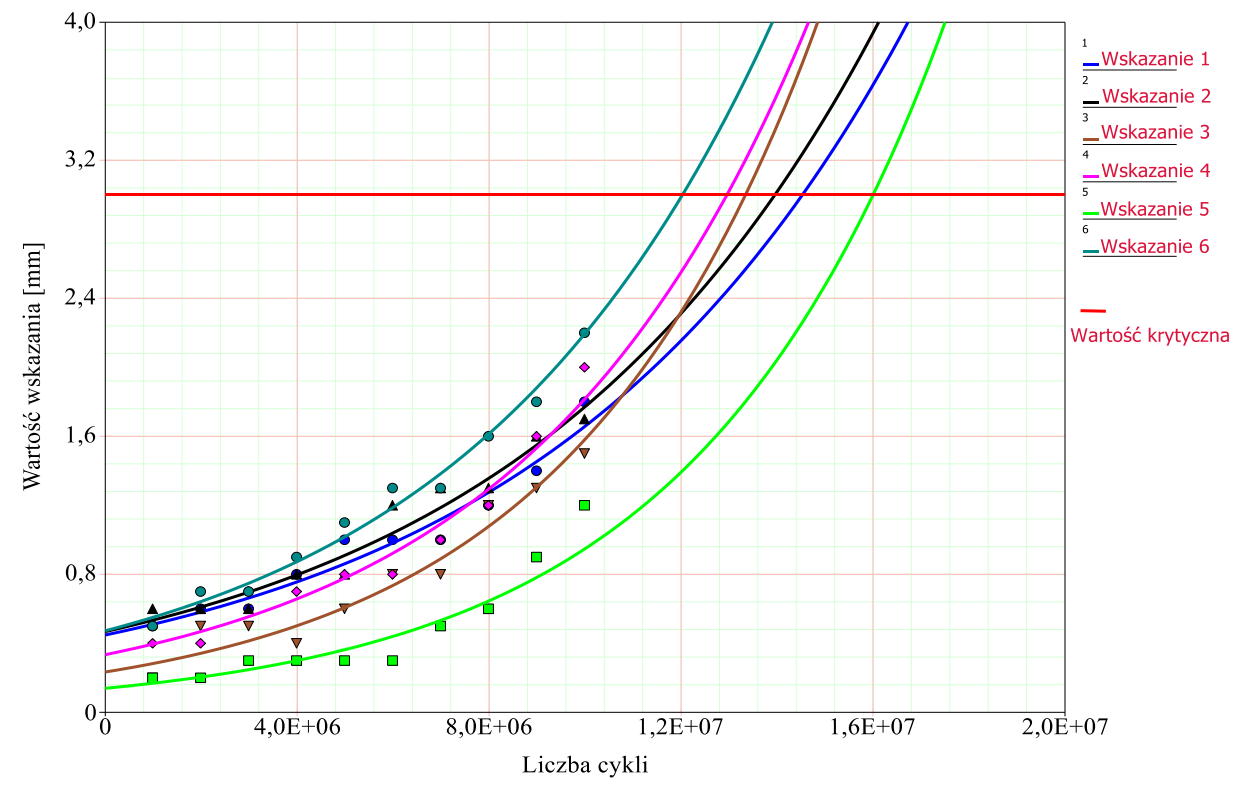

Rys. 1 Dopasowanie rozktadu wyktadniczego do danych empirycznych 
W tabeli 2 zamieszczono obliczone wartości parametrów przyjętego rozkładu wykładniczego dla wskazań zaobserwowanych w trakcie badania.

Tab. 2 Oszacowane wartości parametrów rozkladu wyktadniczego dla zaobserwowanych propagacji pęknięć

\begin{tabular}{|c|c|c|}
\hline \multirow{2}{*}{ Numer wskazania } & \multicolumn{2}{|c|}{ Rozkład wykładniczy } \\
\cline { 2 - 3 } & $\lambda[1 / \mathrm{cyk} 1]$ & $\gamma$ \\
\hline W1 & $1,308767 \cdot 10^{-7}$ & 0,448002 \\
\hline W2 & $1,331323 \cdot 10^{-7}$ & 0,467977 \\
\hline W3 & $1,913162 \cdot 10^{-7}$ & 0,233602 \\
\hline W4 & $1,694182 \cdot 10^{-7}$ & 0,334047 \\
\hline W5 & $1,918339 \cdot 10^{-7}$ & 0,139281 \\
\hline W6 & $1,536321 \cdot 10^{-7}$ & 0,472587 \\
\hline
\end{tabular}

Prognoza parametrów propagacji każdego ze wskazanych pęknięć przeprowadzona dla horyzontu granicznej wartości pęknięcia prowadzi do wyznaczenia liczby cykli obciążenia dla osiągnięcia wyznaczonej krytycznej wartości parametru pęknięcia spoin konstrukcji. Przedstawiono to na rys. 1, gdzie punkty przecięcia się charakterystyk propagacji dla poszczególnych wskazań z linią, odpowiadającą wartości krytycznej pęknięcia, stanowią zbiór danych o uszkodzeniu kolejnych spoin. Wartości te przedstawiono $\mathrm{w}$ tabeli 2. Ponadto, w tabeli tej zamieszczono wartości czasu do uszkodzenia w latach wynikające z liczby cykli obciążeń, na podstawie normy PN-EN 13749:201 i dyrektywy DVS 1612 [3,5].

Tab. 3 Oszacowany czas do uszkodzenia spoiny

\begin{tabular}{|c|c|c|}
\hline Numer & Liczba cykli do uszkodzenia & Czas do uszkodzenia spoiny \\
\hline W1 & 14529478.91 & 44,00 \\
\hline W2 & 13955653,40 & 42,00 \\
\hline W3 & 13343092,71 & 40,00 \\
\hline W4 & 12956616,96 & 39,00 \\
\hline W5 & 16002786,04 & 48,00 \\
\hline W6 & 12029687.04 & 36,00 \\
\hline
\end{tabular}

Uzyskane wyniki poddane zostały dalszemu przetworzeniu dla potrzeb wyznaczenia modelu i parametrów rozkładu prawdopodobieństwa i następnie wskaźników niezawodności, które posłużyły do oceny bezpieczeństwa pracy oraz oceny właściwości eksploatacyjnych badanej ramy. Analiza wyznaczonych wskaźników $R(\mathrm{t}), \lambda(\mathrm{t}), f(\mathrm{t})$ i $F(\mathrm{t})$ dała podstawy do wnioskowania o wartościach trwałości badanej konstrukcji ramy wózka tocznego pojazdu szynowego. 
Assessment of durability of the rail vehicle components with the use of degradation... Ocena trwałości podzespołów pojazdów szynowych z wykorzystaniem metody...

Ponownie jak poprzednio dopasowania modelu dokonano przez zastosowanie testowania zgodności $\mathrm{z}$ wybranymi modelami teoretycznymi (KołmogorovaSmirnowa, Pearsona) metodą największej wiarygodności dopasowania dla danych empirycznych z tabeli 2 . Na podstawie otrzymanych wyników do dalszej analizy wybrano rozkład logarytmiczno-normalny i wyliczone zostały parametry dopasowania rozkładu, którego funkcja gęstości prawdopodobieństwa dana jest zależnością (2) $[8,11,13,22]$ :

$$
f\left(t^{\prime}\right)=\frac{1}{\sigma^{\prime} \sqrt{2 \pi}} e^{-\frac{1}{2}\left(\frac{t^{\prime}-\mu^{\prime}}{\sigma^{\prime}}\right)^{2}}
$$

gdzie:

$\mathrm{t}^{\prime}=\ln (\mathrm{t}) \cdot \mathrm{t}=$ wartości zmiennej losowej

$\mu$ ' - parametr kształtu

$\sigma^{\prime}$ - parametr skali

Wyznaczone wartości parametrów rozkładu logarytmiczno-normalnego są następujące: $\mu^{\prime}=16,436312, \quad \sigma^{\prime}=0,09857$

Na rys. 2 przestawiono odpowiednio: wykres funkcji niezawodności oraz funkcji dystrybuanty rozkładu logarytmiczno-normalnego dla oszacowanych wartości czasu do uszkodzenia konstrukcji ramy wózka tocznego pojazdu szynowego.
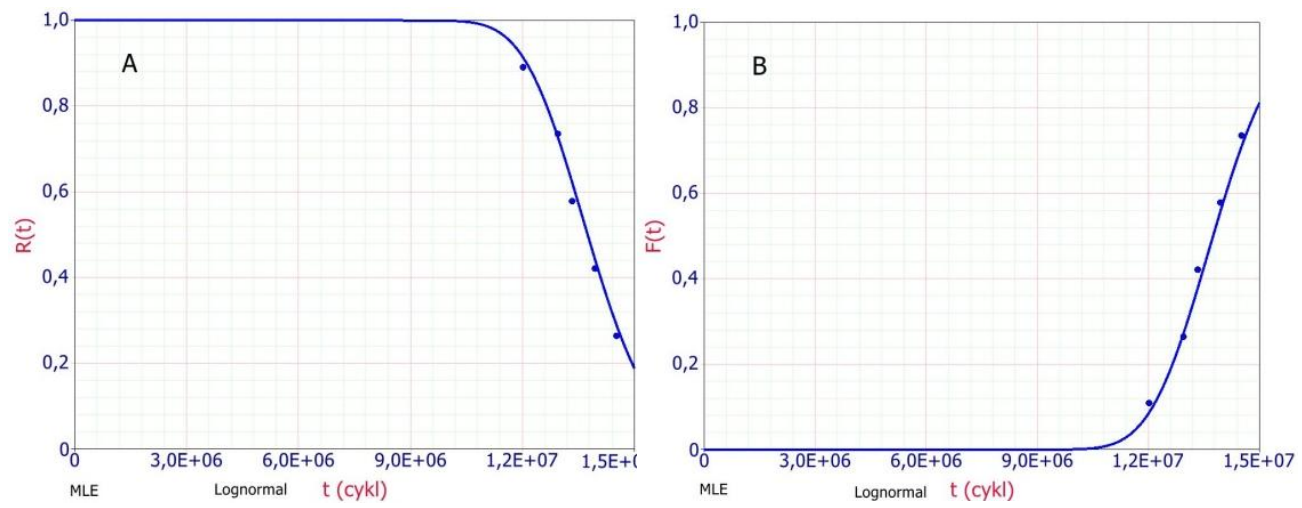

Rys. 2 Charakterystyka funkcji niezawodności $R(t)$ : A Dystrybuanty $F(t)$,

$B$ przedstawione w zakresie oczekiwanego horyzontu przedziału trwałości $1,5 \cdot 10^{7}$ cykli wymuszeń w eksploatacji ramy wózka.

Ważnym wskaźnikiem niezawodności do oszacowania trwałości ramy wózka dla zachowania bezpieczeństwa eksploatacji jest intensywność uszkodzeń. Wartość tego wskaźnika wyraża ryzyko uszkodzenia i stymuluje poziom zachowania bezpieczeństwa w eksploatacji pojazdu szynowego. 
Rysunek 3 dotyczy funkcji intensywności oraz gęstości prawdopodobieństwa uszkodzeń w rozkładzie logarytmiczno-normalnym dla wartości czasu do uszkodzenia konstrukcji.
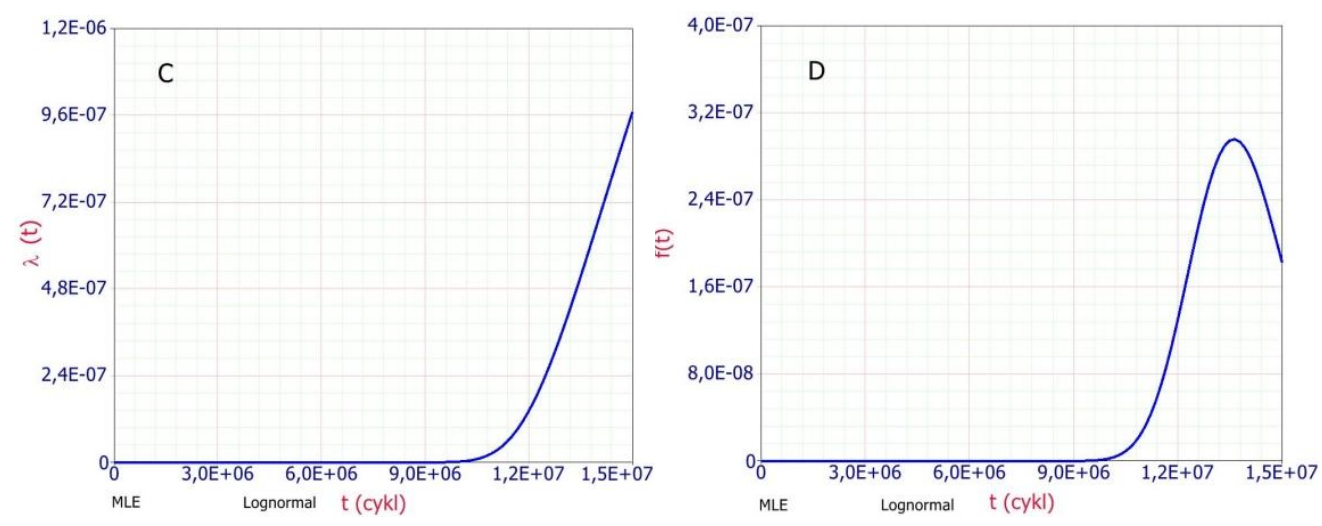

Rys. 3 Charakterystyka funkcji intensywności uszkodzeń $\lambda(t)$ :

C gestości uszkodzeń $f(t)$, D, przedstawione w zakresie oczekiwanego horyzontu przedziatu trwałości do $1,5 \cdot 10^{7}$ cykli wymuszeń w eksploatacji ramy wózka.

Ustalenie granicznych wartości wskaźnika $\lambda(\mathrm{t})$ stanowi warunek dla określenia granicznej wartości trwałości konstrukcji ramy wózka. Prognozowanie na podstawie wyników badań umożliwia oszacowanie maksymalnych wartości intensywności uszkodzeń $\lambda(\mathrm{t})$ oraz gęstości uszkodzeń $f(t)$. Wartości te warunkują ryzyko uszkodzenia ramy i zachowania bezpieczeństwa eksploatacji w analizowanym horyzoncie czasu eksploatacji $\mathrm{T}$.

$\mathrm{Na}$ podstawie obserwacji wybranych charakterystyk i określenia ich granicznych wartości wyliczona została trwałości wyrażona liczbą cykli obciążeń.

Trwałość badanej konstrukcji ramy wózka kolejowego, jako oczekiwany czas zdatności $E T$ w przyjętym rozkładzie logarytmiczno-normalnym oszacowana została na podstawie zależności (3) [11].

$$
E T=\int_{0}^{\infty} t^{\prime} \cdot f\left(t^{\prime}\right) d t=\frac{t^{\prime}}{\sigma^{\prime} \sqrt{2 \pi}} e^{-\frac{1}{2}\left(\frac{t^{\prime}-\mu^{\prime}}{\sigma^{\prime}}\right)^{2}}
$$

Po podstawieniu: $\mu^{\prime}=16,436312, \sigma^{\prime}=0,09857$ otrzymujemy $E T=1,38 \cdot 10^{7}$ cykli

Tak wyrażona trwałość wynosi $1,38 \cdot 10^{7}$ cykli wymuszeń i stanowi zredukowany do sumy obciążeń czas 41 lat pracy ramy wózka w warunkach rzeczywistej eksploatacji.

Weryfikacji uzyskanego wyniku dokonano przez ocenę wartości wyznaczonych wskaźników niezawodności dla wyliczonej trwałości konstrukcji. 
Assessment of durability of the rail vehicle components with the use of degradation... Ocena trwatości podzespołów pojazdów szynowych z wykorzystaniem metody...

Wartości wybranych wskaźników obliczone dla $\mathrm{t}=1,38 \cdot 10^{7}$ cykli obciążeń przyjmują następujące wartości:

$\mathrm{R}\left(\mathrm{t}=1,38 \cdot 10^{7}\right)=0,484354$

$\mathrm{f}\left(\mathrm{t}=1,38 \cdot 10^{7}\right)=2,9500 \cdot 10^{-7}$

$\lambda\left(\mathrm{t}=1,38 \cdot 10^{7}\right)=6,050448 \cdot 10^{-7} / \mathrm{cykl}=2,3294228 \cdot 10^{-5} / \mathrm{h}$

Zastosowanie do oceny trwałości i niezawodności konstrukcji ramy wózka pojazdu szynowego mogą mieć stosowane standardy niezawodności wyrażane jako klasy niezawodności obiektów kwalifikowane na podstawie poziomu intensywności uszkodzeń. Adekwatną dla konstrukcji ramy, jej zadań i warunków eksploatacji jest klasa $\mathrm{T}$, która odpowiada obiektom ważnym, dla których wymagana jest ocena niezawodności i graniczny poziom intensywności uszkodzeń wynosi

$$
\lambda(\mathrm{t})_{\text {gran }}=5 \cdot 10^{-4} / \mathrm{h}>\lambda\left(\mathrm{t}=1,38 \cdot 10^{7}\right)=2,3294228 \cdot 10^{-5} / \mathrm{h}[19] .
$$

Wyniki weryfikacji wartości granicznej intensywności uszkodzeń spełniają kryterium bezpieczeństwa pracy dla szacowanego na podstawie prowadzonych wyliczeń horyzontu trwałości $1,38 \cdot 10^{7}$ cykli wymuszeń obciążających.

\section{Podsumowanie}

W pracy przestawiono wyniki badań zmęczeniowych, dotyczących ramy wózka kolejowego, które posłużyły do oszacowania wybranych wskaźników niezawodności oraz trwałości tej konstrukcji. Analiza probabilistyczna danych o uszkodzeniach dostarczyła informacji do wnioskowania o charakterze czynników prowadzących do uszkodzenia konstrukcji. Istotnym obszarem analizy było wnioskowanie o skutkach obciążeń zmęczeniowych w elementach konstrukcji ramy wózka i ich wpływu na trwałość eksploatacyjną. W procesie analizy statystycznej wykorzystano metodę propagacji zużycia (Degradation Analysis), dostępną w pakiecie oprogramowania firmy Reliasoft. Narzędzie to może mieć zastosowanie również do innych zagadnień inżynierskich, które wymagają przetworzenia danych probabilistycznych w celu oszacowania wartości wybranych miar charakteryzujących trwałość i niezawodność obiektów technicznych. Metoda ta może być stosowana do szacowania wskaźników niezawodności konstrukcji prototypowych, dla których brak jest danych eksploatacyjnych. Oszacowanie trwałości wyliczone na podstawie probabilistycznej prognozy postępu degradacji konstrukcji, które wyniosło 41 lat normalnej eksploatacji może stanowić jedynie wstępną informację o rzeczywistej trwałości konstrukcji. Niezbędne są dalsze badania w rzeczywistych warunkach eksploatacji i kontrola wartości wskaźników niezawodności w kolejnych etapach użytkowania dla zapewnienia horyzontu czasu bezpiecznej eksploatacji ramy wózka pojazdu szynowego. 


\section{Literatura}

[1] Baur K. G.: Drehgestelle - Bogies. EK-Verlag. Freiburg, 2006.

[2] DIN 27201. Zustand der Eisenbahnfahrzeuge - Grundlagen und Fertigungstechnologien - Teil 6: Schweißen.

[3] DVS1612:2009-08 Technische Regel. Gestaltung und Dauerfestigkeitsbewertung von Schweißverbindungen an Stählen im Schienenfahrzeugbau.

[4] EN 12663:2010. Railway applications. Structural requirements of railway vehicle bodies. Part 1 and 2.

[5] EN 13749:2011. Railway applications. Wheelsets and bogies. Methods of specifying structural requirements of bogie frames.

[6] EN 15827:2011. Kolejnictwo -- Wymagania dla wózków i układów biegowych.

[7] Kadziński A.: Studium wybranych aspektów niezawodności systemów oraz obiektów pojazdów szynowych. Monografia naukowa. Wydawnictwo Politechniki Poznańskiej. Poznań, 2013.

[8] Lehmann E. L. Testowanie hipotez statystycznych. PWN. Warszawa, 1968.

[9] Młynarski S., Pilch R., Smolnik M., Kaczor G., Szkoda M., Szybka J.: Effect of Selected Factors on The Safety Integrity Level (SIL). Journal of KONBiN 3(35) 2015, s. 85-98.

[10] Nash F.R.: Reliability assessments: concepts, models, and case studies. CRC Pres Taylor \& Francis Group, 2016.

[11] ReliaSoft Corporation: System Analysis Reference: Reliability, Availability \& Optimization. ReliaSoft Publishing. Tucson, AZ, 2009.

[12] Stapelberg R., F. Handbook of Reliability, Maintainability and Safety in Engineering Design. Springer-Verlag London Limited. Queensland, 2009.

[13] O'Connor P. Practical Reliability Engineering, 4th Edition". John Wiley \& Sons Ltd., 2010.

[14] Romaniszyn Z.: Podwozia wózkowe pojazdów szynowych. Wydawnictwo Politechniki Krakowskiej. Kraków, 2005.

[15] Pilch R.: Reliability evaluation of networks with imperfect and repairable links and nodes. Eksploatacja i Niezawodnosc - Maintenance and Reliability 2017; 19 (1): 19-25.

[16] Pilch R., Smolnik M., Szybka J., Wiązania G.: Koncepcja strategii odnów profilaktycznych na przykładzie pojazdów szynowych komunikacji miejskiej [w] Siergiejczyk M. [red.]: Problemy utrzymania systemów technicznych. Oficyna Wydawnicza Politechniki Warszawskiej, Warszawa 2014.

[17] Ramirez-Marquez J., E., Rocco C., M.: All-terminal network reliability optimization via probabilistic solution discovery. Reliability Engineering and System Safety 2008; 93: 1689-1697.

[18] Scharman D., Hiller M., Bardini R.: Vehicle dynamics, modeling and simulation, Springer - Verlag Berlin Heidelberg, 2014. 
Assessment of durability of the rail vehicle components with the use of degradation... Ocena trwatości podzespotów pojazdów szynowych z wykorzystaniem metody...

[19] Smalko Z.: Podstawy projektowania niezawodnych maszyn i urządzeń mechanicznych. PWN. Warszawa, 1972.

[20] Sowa A.: Ocena stanu technicznego pojazdów szynowych na podstawie cech zdeterminowanych. Politechnika Krakowska im. Tadeusza Kościuszki. Kraków, 2013

[21] Szkoda M., Kaczor G.: RAMS analysis of railway vehicles' lifecycle. Journal of KONBiN nr 41/2017, s. 83-106.

[22] Szkoda M., Kaczor G.: "Reliability and availability assessment of diesel locomotive using Fault Tree Analysis". Archives of Transport, 2016, Vol. 40, Issue 4, s. 79-89.

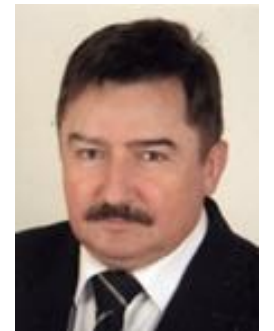

Dr inz. Stanistaw Młynarski ukończyt studia na Wydziale Mechanicznym Politechniki Krakowskiej. Ukończyt studia doktoranckie na Wydziale mechanicznym PK i uzyskat stopień doktora nauk technicznych. Obecnie pracuje na stanowisku adiunkta. Specjalizuje się $w$ dziedzinie eksploatacji, niezawodności oraz bezpieczeństwa maszyn, pojazdów i systemów technicznych. (Udziat 33,3\%)

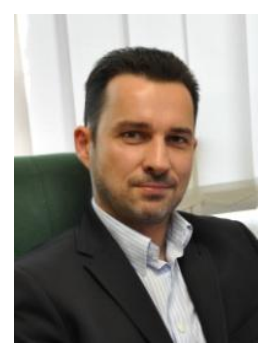

Dr hab. inz. Maciej Szkoda jest absolwentem Wydziatu Mechanicznego Politechniki Krakowskiej. Pracuje w Instytucie Pojazdów Szynowych PK na stanowisku adiunkta naukowodydaktycznego. Petni funkcje dyrektora Instytutu. Specjalizuje się $w$ ocenie efektywności $i$ niezawodności systemów $i$ środków transportu. (Udziat 33,3\%)

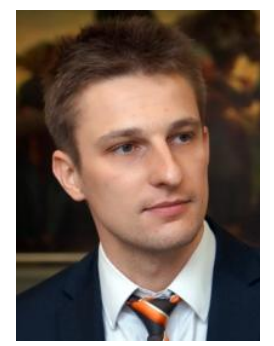

Dr inż. Grzegorz Kaczor ukończyt studia magisterskie na Wydziale Mechanicznych Politechniki Krakowskiej, gdzie kontynuuje nauke na studiach III - ego stopnia. Pracuje w Instytucie Pojazdów Szynowych PK na stanowisku asystenta naukowo-dydaktycznego. Gtówne obszary zainteresowania to ocena niezawodność $i$ bezpieczeństwa środków transportu $z$ wykorzystaniem metod symulacyjnych. (Udziat 33,3\%) 